4 norden 



\section{Increased exchange in the Building Sector}

Network for joint R\&D - Nibcor Phase 1\&2

Lone Møller Sørensen

Kristian Storgaard

TemaNord 2009:524 
Increased exchange in the Building Sector

Network for joint R\&D - Nibcor Phase 1\&2

TemaNord 2009:524

(C) Nordic Council of Ministers, Copenhagen 2009

ISBN 978-92-893-1849-5

Print: Kailow Express ApS

Printed on environmentally friendly paper

This publication can be ordered on www.norden.org/order. Other Nordic publications are available at www.norden.org/publications

Printed in Denmark

Nordic Council of Ministers

Store Strandstræde 18

DK-1255 Copenhagen K

Phone (+45) 33960200

Fax (+45) 33960202

www.norden.org

\section{Nordic Council}

Store Strandstræde 18

DK-1255 Copenhagen K

Phone (+45) 33960400

Fax (+45) 33111870

\section{Nordic co-operation}

Nordic cooperation is one of the world's most extensive forms of regional collaboration, involving Denmark, Finland, Iceland, Norway, Sweden, and three autonomous areas: the Faroe Islands, Greenland, and Åland.

Nordic cooperation has firm traditions in politics, the economy, and culture. It plays an important rol in European and international collaboration, and aims at creating a strong Nordic community in a strong Europe.

Nordic cooperation seeks to safeguard Nordic and regional interests and principles in the global community. Common Nordic values help the region solidify its position as one of the world's most innovative and competitive. 


\section{Content}

Preface

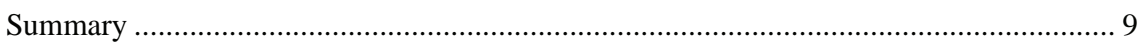

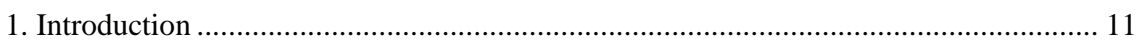

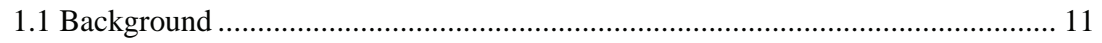

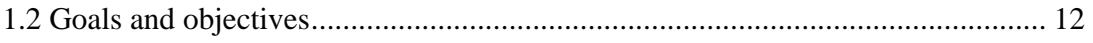

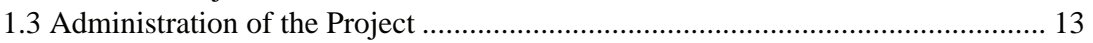

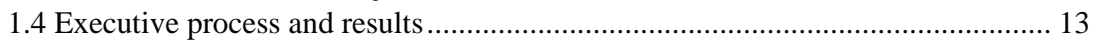

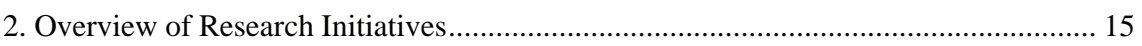

2.1 Overview of existing research initiatives on regional level ................................ 15

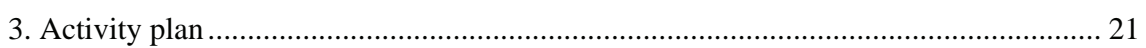

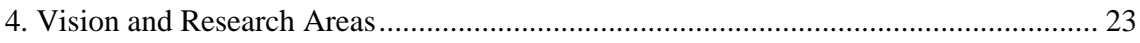

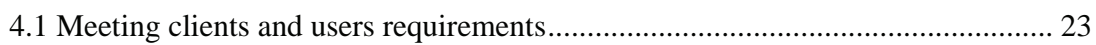

4.2 Transformation of the Construction Sector ........................................................ 24

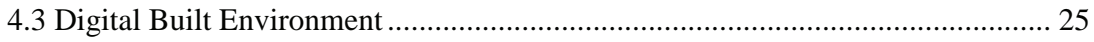

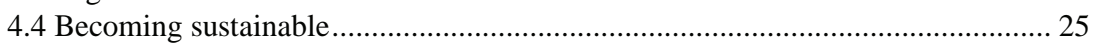

4.5 Building technology and high added value materials .......................................... 26

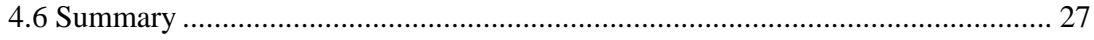

4.7 Objective and action for the programme ....................................................... 27

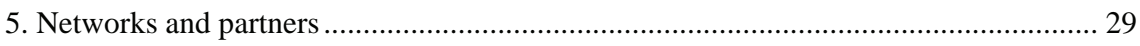

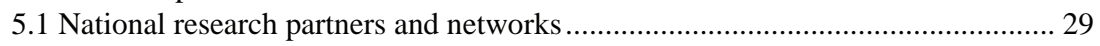

5.2 Objective and Action for the programme ........................................................... 33

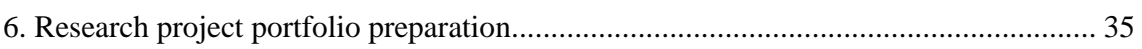

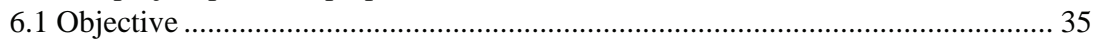

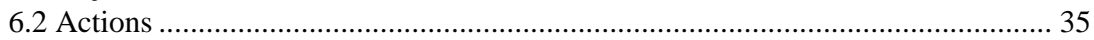

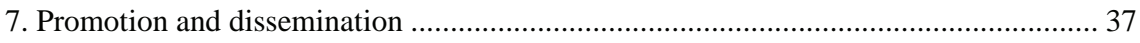

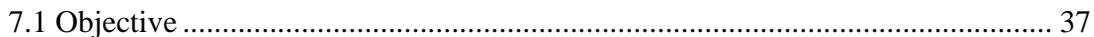

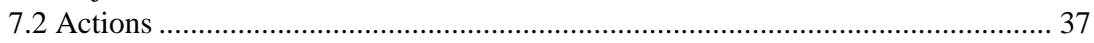

8. Phase 2: Workshop and Nibcor Home site …............................................................. 41

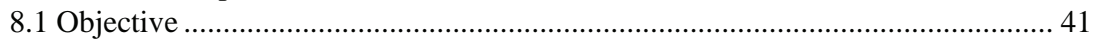

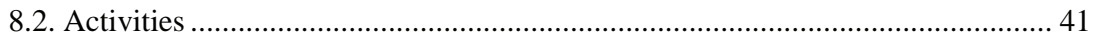

8.3 Output from Phase 2 2..................................................................................... 43

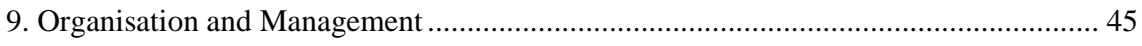

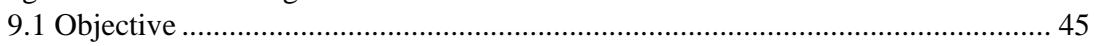

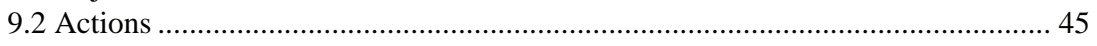

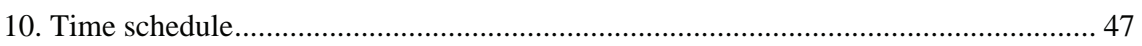

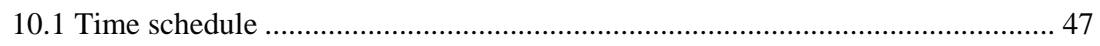

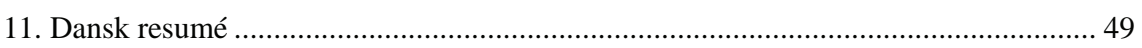

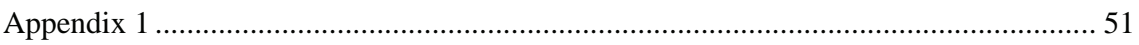

National input on research for Nibcor from participating countries ............................ 51

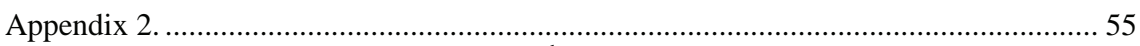

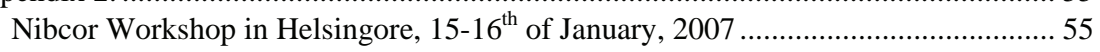

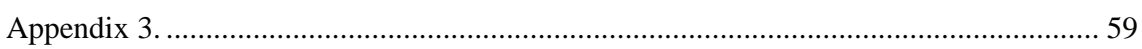

EOI for NICe Call: Support for Innovative Construction........................................... 59

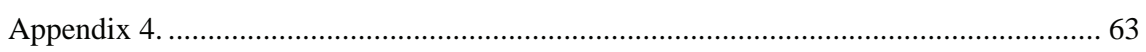

Full proposal for the NICe Call: Support for Innovative Construction........................ 63 



\section{Preface}

In 2004 the Nordic Council of Ministers agreed on the Action Plan ' Increased exchange in the building sector between countries in the Northern Dimension region'. The Northern Dimension region covers Denmark, Estonia, Finland, Iceland, Latvia, Lithuania, Norway, Poland and Sweden. Among activities to fulfil the Action Plan was the Nibcor project. The objective of the project has been to develop a cooperation programme, to select themes and to establish networks for stakeholders in the building sector from industry, governmental bodies and research for realization of $R \& D$ projects.

The results of the Nibcor project are presented in this report.

The Nibcor project has been managed by a steering group, comprising Director Lone Møller Sørensen, SBi, (project leader), senior researcher Kresten Storgaard, SBi, and Professor Bengt Turner, Uppsala University, until his all too early death. From January 2007 Professor Rune Wiberg, Uppsala University, has taken up his function.

A working group with one member from each of the countries has worked out the selection of themes, and has been core stakeholders in establishing a network from industry, government and research, as well as in the work at a workshop for the network, held in Helsingore, January, 2007. Also, representatives from international research funding bodies in the Nordic countries and in the EU, has participated.

The Coordinator of the programme, Bengt Nyman, has contributed to the results by participating in the workshops as well as in the ongoing analyses and discussions on which the report is produced.

All who has contributed to the work is hereby thanked for their contribution.

Lone Møller Sørensen

Project Leader 



\section{Summary}

High prices, low competition and a high degree of local market are characterising the building and construction market today. It is assumed that a more transparent and harmonized building and construction market in the Northern region will improve the single market between the countries in the region and reduce the housing cost through reduction of construction costs and building prices. This is the objective of the Action Plan 'Increased exchange in the building sector between countries in the Northern Dimension region' under the Nordic Council of Ministers. The Northern Dimension region covers Denmark, Estonia, Finland, Iceland, Latvia, Lithuania, Norway, Poland and Sweden.

Co-operation and exchange of knowledge are important premises for trade to be facilitated and mobility and cross-border construction activities to be stimulated. R\&D plays an important role in this context by contributing with conducting survey, sharing information and developing new knowledge.

A larger and more transparent market will offer new opportunities for $\mathrm{R} \& \mathrm{D}$ in processes, products and services and thereby providing new opportunities for increased productivity in the building and construction sector as well as obtaining a higher degree of understanding and fulfilment of user and society needs in buildings and the built environment.

This project, Nibcor is intended to be fulfilled in two stages. This report covers the result of both phases.

The first phase had the objective to develop a cooperation programme for a network for joint $R \& D$ relevant to the issues of the action plan.

A number of regional or European research initiatives covering both networks and funding programmes for building and construction exists. Even though some of the programmes have elements which could support the Action Plan, none of these have the same research objectives as this Action Plan.

Therefore developing and establishing a cooperation programme for a regional network for joint R\&D in building and construction relevant to the issues in the Action Plan is identified as a central part of the Action Plan. However cooperation with relevant networks and funding programmes will be an important part of the Nibcor project. In addition a joint R\&D network in the region will strengthen the research capabilities in the region and provide an excellent platform for influence on and success in the Regional and European Research programmes.

Through a workshop and correspondence with a national member of each country in the Northern Dimension three research areas was identified as key focus areas for Nibcor: 
- Meeting client and users requirement,

- Transformation of the Construction Sector,

- Digital Built environment.

These were selected as important research areas for reduction of barriers to cross-border transfer of research, knowledge and building activities.

Further an initial screening of research partners in the Northern Dimension has given a first overview of the research partners. This shows a potential for an increased R\&D cooperation both with partners with similar and with complementary research competence.

The objective of phase 2 of the project has been to establish a regional network for joint R\&D in building and construction covering research issues relevant for the Action Plan. Phase 2 included an activity plan for establishing a regional network for joint R\&D, Nibcor covering:

- Vision and research areas - Confirmation of key focus research areas,

- Mapping of research partners and barriers for cooperation,

- Research project portfolio preparation - from exchange of ideas to support and facilitate combined research initiatives,

- Promotion and dissemination - activities to support and facilitate the network.

Central has been the completion of a workshop for stakeholders in the building industrial complex, including firms, researchers and administrators to identify central themes for research and development.

A home site for the Nibcor project was established as well, for information and communication between stakeholders in the sector.

A phase three, concerning completion of R\&D projects with commercial potentials for the sector has not yet been completed, but funding has been sought without success so far. 


\section{Introduction}

\subsection{Background}

High prices, low competition and a high degree of local market are characterising the building and construction market today. It is assumed that an increased cross-border exchange and co-operation in the Nordic Dimension countries ${ }^{1}$ will:

- Improve the single market of the European Union between the countries in the region;

- Reduce the housing cost through reduction of the construction costs and building prices.

Co-operation and exchange of knowledge are important premises for trade to be facilitated and mobility and cross-border construction activities to be stimulated. R\&D plays an important role in this context by contributing with conducting survey, sharing information and developing new knowledge.

A larger and more transparent market will offer new opportunities for $\mathrm{R} \& \mathrm{D}$ in new processes and cooperation forms, new tools and methods for utilisation of ICT, new materials and design solutions. Thereby providing new opportunities for increasing productivity in construction and building sector as well as obtaining a higher degree of understanding and fulfilment of user and society needs in buildings and the built environment. In addition this will support development of a more sustainable construction and building sector and improve the innovation up-take in the sector. Further a harmonisation of building regulations and free mobility of labour will provide an important basis for the single market in the Northern Dimension region.

More transparent markets in terms of housing demand, economics and demography as well as the local legislation and building culture will potentially expand the markets from highly local markets to a regional single market. In addition, household mobility and economic interaction will change the housing landscape in all countries. Analytical instruments and new approaches that can support the development of a more transparent market will provide new opportunities for a more efficient housing market with a higher fulfilment of user and society needs.

Historically there has been a considerably R\&D cooperation within the Nordic countries based on similarities in culture, climate and tradi-

\footnotetext{
1 Denmark, Estonia, Finland, Iceland, Latvia, Lithuania, Norway, Poland and Sweden
} 
tions. This is now being gradually expanded to the other countries in the Northern Dimension countries. However lack of funding possibilities and other incentives for joint $R \& D$ is creating greater barriers to future expansion of joint $R \& D$ in the region.

A joint network for $R \& D$ in the region will strengthen the research capabilities and possibilities for joint research projects utilising the regional advantages. Further it will provide an excellent platform for influence on and success of the European research programmes and consideration for a joint European Research Area (ERA). In particular it will support and strengthen the possible outcome of the European Construction Technology Platform (ECTP) for the region. Further the joint Network for R\&D will be an important research advisory panel for decisionmakers in the various countries regarding research aspects on building and construction. In the long term, the network will contribute to a more transparent and harmonised building and construction market in the Northern Dimension region.

\subsection{Goals and objectives}

\subsubsection{Objectives of the Action Plan}

This project is part of a large-scale Action Plan 'Increased exchange in the building sector between countries in the Northern Dimension region' under the Nordic Council of Ministers. The primary objectives of the Action Plan are:

- To promote increased cross-border exchange and co-operation in the building and construction sector and to

- To improve the Single Market of the European Union between countries in the Northern Dimension aiming at

- Reducing high housing costs through the reduction of construction costs and building prices.

\subsubsection{Goals and objectives of the Nibcor Project}

The overall goal of this project, Nibcor is to develop and establish a cooperation programme for a regional network for joint R\&D in building and construction relevant to the issues in the action plan.

The project is intended to be fulfilled in two phases. The objective of the first phase is:

To develop a co-operation programme for a network for joint R\&D relevant to the issues in the action plan. 
The objective of the second phase is:

To establish a regional network for joint R\&D in building and construction, that can contribute to identification of research challenges (of common interest), dissemination of knowledge and to strengthen the research co-operation in the region.

The objective of a third phase will be to support the running of a regional network for joint R\&D in building and construction, Nibcor, and thereby supporting identification of research challenges of common interest, dissemination of knowledge and strengthening the research co-operation in the region.

\subsection{Administration of the Project}

The Steering Group of the Action Plan discussed the project and made useful comments concerning the first phase of the project. The project management was carried out by the Nibcor Steering Group comprising Director Lone Møller Sørensen (project leader) and senior researcher Kresten Storgaard, Danish Building Research Institute, and Professor Bengt Turner, Uppsala University until his all too early death. Thereafter Professor Rune Wigren, Uppsala University has taken up his function.

A working group with one member from each of the participating countries was established according to the Action Plan. Together with the Nibcor Steering Group the Working Group provided a proposal for the next phase of the project. The Nibcor Working Group was a central actor in the Nibcor programme, phase 2. At a workshop in Helsingore, Denmark in January 2007, and at a following working group meeting, themes for further action were taken.

\subsection{Executive process and results}

All members of the Working Group have participated in providing input and initial prioritising of the research topics at the Workshop in Copenhagen on $26^{\text {th }}$ of June 2006. Except for the members from Poland and Latvia who due to political situation and the time constraint for the project were not able to provide input for the first phase. Further the workshop was attended by the Coordinator of the programme Bengt Nyman. Keynote presentation was given at the workshop by Christophe Lesniak, DG Research EU Commission and by Knud-Erik Busk, chairman of the Danish Client Association, Chairman of the Danish National Technology Platform and Member of ECTP High Level Group. A draft report has been circulated to all members of the Working Group for correction and approval. 
The Working Group members participated in the Nibcor workshop for stakeholders in the building segment, in January 2007, in Helsingore. In a following workshop for the Working Group, decisions for further dissemination on the Nibcor home site on three themes was decided and carried out by the administrative group. 


\section{Overview of Research Initiatives}

\subsection{Overview of existing research initiatives on regional level}

Below an overview of the major existing research initiatives is given covering both networks and initiatives by funding organisations with influence on the region of the Northern Dimension.

\subsubsection{European Construction Technology Platform - ECTP}

The European Construction Technology Platform (ECTP) was launched in October 2004 at the B4E Conference. ECTP is a network formed by all stakeholders in the building and construction sector with the purpose of positioning the sector for the coming research programme in Europe (see www.ectp.org). The technology platforms are an instrument founded by the European Commission and are industry lead. Today ECTP is supported by representatives of major stakeholders of the construction sector and by the European Commission. It gathers more than 700 individual members working at the European level. The ECTP has developed a vision for a sustainable and competitive construction sector by 2030 .

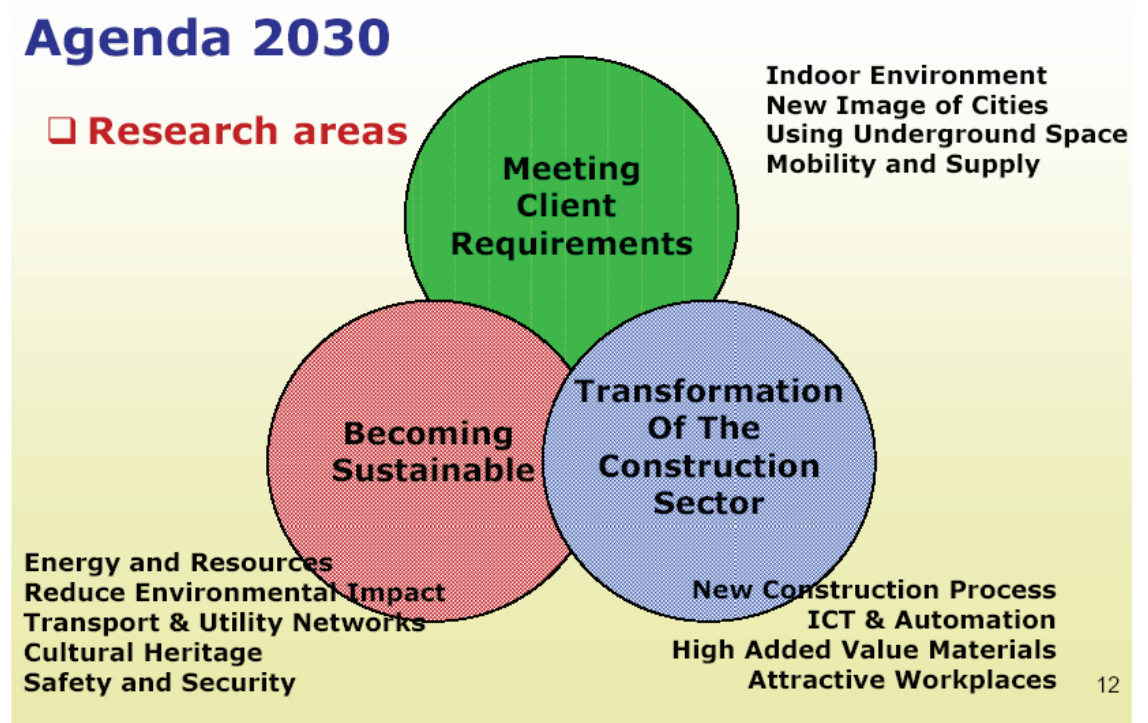

Figure 1. ECTP Vision 2030 
Based on the vision and the research agenda ECTP has identified the following priorities for research:

- New technologies, concepts and high tech materials for efficient and clean buildings,

- High added value construction materials,

- Reduced environmental and man-made impacts on landscape and cities,

- Improved safety and security,

- New integrated processes,

- A living cultural heritage for an attractive Europe,

- Underground innovative construction technologies,

- Sustainable management of transports and utilities networks,

- Nanotechnologies for materials in construction.

ECTP is in close dialogue with the Commission and the relevant DG's about research priorities for the European Framework programme, FP7.

\subsubsection{National Construction Technology Platforms}

In order to involve the many stakeholders of the construction sector a network of National Construction Technology Platforms was established under ECTP. Today more than 25 national platforms exist in Europe. For a large number of the participating counties in the Northern Dimension region a national platform has been established or is in process of being established.

Table 1. Overview of countries with national platforms in the Northern Dimension region

\begin{tabular}{ll}
\hline Denmark & Norway \\
Finland & Poland \\
Estonia & Sweden \\
Lithuania & \\
\hline
\end{tabular}

The vision and the research agenda of ECTP has partly been adopted by National Technology Platforms in most of the participating countries in the Northern Dimension region.

Together with 18 National Platforms ECTP has launched a Eureka Umbrella on construction related projects to develop some SRA priorities through Eureka projects. 


\subsubsection{European Network for Housing Research - ENHR}

The European Network for Housing Research, ENHR:

- sponsors major international conferences every two years,

- publishes a comprehensive Newsletter four times a year,

- provides a framework for nearly twenty working groups,

- encourages smaller conferences and seminars every year,

- has an active group of PhD students (new housing researchers). (See: www.enhr.ibf.uu.se/).

The Network is composed of researchers from a variety of social science disciplines dealing with housing and urban issues. In addition to its basic goal of supporting research, the Network also seeks to promote contacts and communications between researchers and practitioners within the housing field. Membership can either be in the form of individual membership or of institutional membership.

ENHR was established in 1988 and now has more then 1000 individual and nearly 100 institutional members representing every country in Europe. In addition to a general assembly held every two years, the ENHR is directed by a democratically elected board, the Coordination Committee. A secretariat including the editorship of the ENHR Newsletter is located at the Institute for Housing and Urban Research, Uppsala University, in Gävle, Sweden.

\subsubsection{European Network for Building Research Institutes - ENBRI}

The European Network for Building Research Institutes (ENBRI) links the leading, non-academic centres for building and construction research in Europe (see: www.enbri.org/). Its 21 members employs in total over 3000 professional research staff. The aims of ENBRI are:

- To promote cooperation among its members, and with the European Commission and stakeholders of the European construction sector, in order that ENBRI members may contribute effectively to the improvement of competitiveness, sustainability, quality and safety of the build environment,

- To promote the benefits of investment and development in construction and the built environment at regional, national and European levels,

- To advise policy makers and wider public on issues related to research and innovation in the built environment.

Key elements in supporting these aims are research, innovation and knowledge transfer activities for development of the built environment. 
Based on the challenges that the built environment is facing today and its strong link with both industry and government bodies and their broad expertise within in the built environment it is the vision of ENBRI to contribute to the development of a sustainable and knowledge-based European construction sector, which is competitive, innovative, market driven and meets users and societal needs by providing the best living and working conditions for all people.

The main action lines identified to reach this vision are respectively concerned with:

- Raising environmental standards,

- Fulfilling user and stakeholder requirements and aspirations,

- Changing construction processes and relationships,

- Updating and improving the built environment,

- Exploiting new materials and technologies,

- Promoting education and training, knowledge transfer, quality employment and innovation.

\subsubsection{Nordic Innovation Centre}

The Nordic Innovation Centre is the Nordic Council of Ministers single most important instrument for promoting an innovative and knowledgeintensive Nordic business sector (see: www.nordicinnovation.net/). The basic assumption is that each of the Nordic countries possesses knowledge, which through increased co-operation significantly will improve innovation capabilities and competitiveness for Nordic businesses.

\section{Nordic knowledge platforms}

Today, the Nordic Innovation Centre is an important player in Nordic knowledge platforms within the areas of innovation policy, creative industries, biotechnology, food safety and innovative building \& construction. Establishing common Nordic knowledge platforms on strategically important areas give Nordic businesses access to the best knowledge possible and greatly enhance their innovation capabilities. It is the believing that building common Nordic knowledge markets are vital to all Nordic business life, enabling firms and institutions to compete in a global market which is becoming more and more knowledge driven.

\section{Investments}

The total project portfolio of the Nordic Innovation Centre consists of approximately 120 ongoing projects and networks. Together with several hundred completed projects of great value to Nordic businesses, these projects involve the Centre in nearly all strategically important Nordic areas. 


\section{Innovative Building}

One of the preconditions for living in the Nordic Region is a building shield is of high quality. The traditional market in building and building materials are under change, pushed by new materials, new transnational regulations and a free market for services and labour. A vision can be to:

"Establish and develop a new approach for the Nordic property and construction industry - while there are still opportunities. Go in advance of the rest of Europe in working for change that entails very profound consequences for both society and the individual”.

\subsubsection{ERABUILD}

ERABUILD is a strategic cooperation between national programmes promoting sustainable construction and operation of buildings (see: www.erabuild.net/). ERABUILD aims at having a major impact on creating the European Research Area (ERA) in research on sustainable development in the construction and operation of buildings. A step towards this aim is planning and preparing a trans-national R\&D programme in the area. A short term goal for the project is the development of a learning network of governmental organisations. The ERABUILD will be running from 2004-2007 and the partners are: Finland, Austria, Denmark, France, Germany, Netherlands, Sweden and United Kingdom.

ERABUILD has identified the following three areas for future research needs:

- Renovation and Maintenance,

- Energy in the Building Sector,

- Processes.

So far three joint-calls have been carried out with the following titles:

- Managing information in construction,

- RFID - state of art report,

- Transformation of the construction sector through industrialisation.

\subsubsection{Summary}

None of the identified networks or initiatives by funding organisations has the same research objectives as the Action Plan. However most of those have elements which could support the Action Plan. Therefore it will be an important part of Nibcor to co-operate with the relevant networks and funding programmes. Through Nibcor it will be possible to strengthen the synergy between the relevant parts of the other programmes and networks for the benefit of the Action Plan. 



\section{Activity plan}

Based on the Action Plan, initial mapping of research initiatives and the workshop in Copenhagen in June 2006 the following activity plan has been identified for the Nibcor programme:

- Vision and research areas,

- Networks and partners,

- Research project portfolio preparation,

- Promotion and dissemination.

In the following the objectives and the actions for each part of the programme are described. 



\section{Vision and Research Areas}

The primary objectives of the Northern Dimension Action Plan are to contribute to a more transparent and harmonized building and construction market in the Northern Dimension region.

Primary objectives of the Action Plan are:

- To promote increased cross-border exchange and co-operation in the building and construction sector and to

- To improve the Single Market of the European Union between countries in the Northern Dimension aiming at

- Reducing high housing costs through the reduction of construction costs and building prices.

As a central part of the initial phase of the project a workshop was held in Copenhagen with national representatives of the participating countries of the Northern Dimension region. The national input on research areas for the Nibcor programme are given in appendix. Through the workshop and a following up correspondence the following five research areas were identified as potential main topic areas for the proposed Nibcor programme:

- Meeting clients and users requirements,

- Transformation of the Construction sector,

- Digital Built Environment,

- Becoming Sustainable,

- Building technology and high added value materials.

Together they will have the potential to support the development and expansion of the Northern Dimensions markets from highly local markets to a regional single market, a demand-driven market with more innovation, higher quality and reduced construction costs and building prices.

\subsection{Meeting clients and users requirements}

\subsubsection{Market/Business drivers, impacts and potential}

- Increased demand for customer and end user influence on the design of products and systems; diversification of the customer and user segments based on demography, wealth, region, trend etc.; 
- Increased quality requirements on the performance of the built environment and increased capabilities to simulate the psychical phenomena and human response;

- Transparent markets in terms of housing demand, economics and demography, legislation and regulation;

- Pressure to reduce construction costs and building prices through better procurement.

\subsubsection{Research focus and scientific goals}

- Understanding and defining user and society future needs in a business perspective;

- Demand studies (modelling and forecasting of build and human environment) including housing wealth, mobility and demographic changes, cost of building and planning regulations,

- Total lifecycle management;

- Value-based procurement including new procurement methods and their legal barriers in terms of partnerships and operation etc (publicprivate partnerships (BOOT, BOT));

- Financial integration and guarantee systems for clients/residents;

- Knowledge base of best practice including user feedback, benchmarking;

- Remove barriers in regulations as a basis for deliberations in possible harmonization - identification \& research of consequences on possible changes.

\subsection{Transformation of the Construction Sector}

\subsubsection{Market/Business drivers, impacts and potential}

- Increased global competition, low profit margin in the sector, fragmented sector dominated by small firms, bad image and safety record, low quality, high price;

- Pressure to increase productivity and quality in the construction sector;

- Diminishing workforce in general or for construction sector will increase the need to increase the productivity and attract other groups of resources.

\subsubsection{Research Focus and scientific goals}

- New integrated processes (partners, industrialization, productivity, claims by delivery; 
- Competence requirements and free mobility of resources (labour, materials and activities;

- Impact of shadow market/economy;

- Building cost analysis + management studies, competition;

- Remove barriers in regulations as a basis for deliberations in possible harmonization - identification \& research on consequences of possible changes.

\subsection{Digital Built Environment}

\subsubsection{Market/Business drivers, impacts and potential}

- Due to aging and diminishing workforce as well as increased global competition there is a pressure to radically improve the productivity of the whole real estate and construction sector from the product manufactures to the owner;

- Need for better, more flexible and reliable control of conditions and operating costs according to diverse customer requirements;

- High business potential.

\subsubsection{Research Focus and scientific goals}

- New integrated construction processes with dynamic supply networks (web, e-integration) including digital tender and pro-curement, both internal and across company boundaries in the building process;

- Information management over the lifetime of the products and systems in the built environment;

- Integrated product models: interoperability, simulation and visualization;

- ICT-based services for mobile users;

- Ubiquitous environment: sensor networks combined with adaptable materials;

- Life-long learning and intelligent tutoring systems.

\subsection{Becoming sustainable}

\subsubsection{Market/Business drivers, impacts and potential}

- The built environment accounts for nearly $50 \%$ of the resource consumption and has a large environmental impact. With the consideration for the environment and energy shortage there is a huge need for development of concepts, business models, technology, materials and 
solutions for energy and resource reduction, which generates new business opportunities;

- A high percentage of the people live in the cities. However due to wealth, pollution, quality of housing and urban areas people are increasingly moving out of the inner city. Therefore there is a huge need to upgrade a large proportion of the building stock and urban areas;

- Urban sprawl as a result of conflicting individual demands and societal needs for less traffic, less energy consumption;

- Public and commercial demand for measures against crime and terror and to mitigate consequences of accidents and natural disasters.

\subsubsection{Research Focus and scientific goals}

- New technologies, concepts, business models and materials for resource efficient and clean buildings and urban areas based on users needs and lifecycle management;

- Total lifecycle management - modelling, forecasting and operation of the build and human environment;

- Integrated design tools, information systems and manufacturing technologies for high efficient buildings (energy, raw materials, water, low energy industrial processes) fulfilling users needs in terms of comfort, design and price;

- Detection, identification, protection and assessment methods for safety and security of people, critical infrastructures, industrial production systems;

- Urbanisation, suburbanisation and urban sprawl; Segregation and integration - social cohesion;

- Remove barriers in regulations as a basis for deliberations in possible harmonization - identification \& research on consequences of possible changes.

\subsection{Building technology and high added value materials}

\subsubsection{Market/Business drivers, impacts and potential}

- Quest for more carefree, durable, safe and economical products in various industrial and consumer applications to fulfil user requirements including customized properties;

- Demand for sustainable growth, reduction of environmental impact: less materials, durable materials and recycle materials. 


\subsubsection{Research Focus and scientific goals}

- Durability /rehabilitation, performance of products and structures under long-term or extreme exposure;

- Building technology;

- New materials and design solutions, new-fibre based, high added value building products, new and modified materials and methods to bond materials into composites and structural systems;

- Functional and nano materials using new technologies of bio, nano and it to provide new performance and value of buildings products and systems to the end-user.

\subsection{Summary}

In the Nibcor programme it is recommended especially to focus on the topics important for reduction of barriers to cross-boarder transfer of research, knowledge and building activities. The following three areas are seen as especially important:

- Meeting client and users requirement,

- Transformation of the Construction sector,

- Digital Built Environment.

\subsection{Objective and action for the programme}

\subsubsection{Objective}

The objective for this part of the Nibcor programme is to get confirmation of the main topic research areas from the Northern Dimension Steering Group and the research network.

\subsubsection{Action}

- To present the result of phase 1 and the proposal for the full programme of Nibcor to the Steering Group of the Northern Dimension including confirmation of the main topic research areas;

- To obtain confirmation from the research network in the initial phase of the research project portfolio preparation (see page 22). 



\section{Networks and partners}

In all countries in the Nordic Dimension Region research in Building and Construction deliver important results for the industry and governmental bodies, participate in education of students to the sector, and participate in international cooperation. But scope, amount of research effort, strength and focus differ to some degree. This also accounts for the national partners performing building and construction research. Below is given an initial overview of the main national research actors in the field.

The overview is based on the workshop for the Nibcor working group, taking place at SBi, Copenhagen, in June 2006, and supplementary inputs from the working group.

Table 2. The Nibcor Working Group

\begin{tabular}{ll}
\hline $\begin{array}{l}\text { Denmark } \\
\text { Project Leader }\end{array}$ & $\begin{array}{l}\text { Ms. Lone Møller Sørensen, Director } \\
\text { Decretariat }\end{array}$ \\
Iceland & Kresten Storgaard, Senior Researcher, SBi \\
& $\begin{array}{l}\text { Mr. Haakon Olafsson, Director } \\
\text { IBRI - Icelandic Building Research Institute }\end{array}$ \\
Estonia & Mr. Roode Liias, Professor, Dean, Faculty of civil engineering, Tallinn \\
& University of Technology \\
Latvia & Mrs. Silvija Strausa, Latvia University of Agriculture \\
Lithuania & Mr. Arturas Kaklauskas, Professor \\
Finland & Vilnius Gediminas Technical University \\
Mr. Matti Kokkala, Research Director \\
Norway & VTT Technical Research Centre of Finland \\
Poland & Mr. Bjørn Svensvik, Professor, Director, SINTEF Bygforsk \\
Sweden & Mr. Roman Gajownik, ITB \\
& $\begin{array}{l}\text { Mr. Bengt Turner, Professor, Chair, Institute for Housing and Urban Re- } \\
\text { search, Uppsala University, Sweden }\end{array}$ \\
Mroject Coordination & Bengt Turner, IBF Uppsala University, Lone Møller Sørensen, SBi, Rune \\
Group & Wigren, Professor, Uppsala University. \\
Programme & Mr. Bengt Nyman, Director \\
Boordinator & \\
\hline
\end{tabular}

\subsection{National research partners and networks}

\subsubsection{Sweden}

In Sweden research in building and construction are carried out on the main Universities and Technological High School. Institute for Housing and Urban Research (IHUR) at the University of Uppsala is a multidisciplinary research department which covers a wide variety of issues con- 
cerning housing and the built environment. Mainly financed by the university budget (75 pct) also external funding from research fund and various partners are seen, including EU programmes. In Interreg III B programmes projects in the Baltic region is carried out. In the research the institute emphasis cooperation with the other departments at Uppsala University and in other parts of the academic environment and the importance of large, coordinated projects, where a thematic and disciplinary focus is integrated.

The international cooperation is encouraged and there are cooperation agreements with large research departments in Europe (Delft, Glasgow, Cardiff, York, Berlin). The Institute has in-house international journals as HTS (Housing, Theory and Society) and EJHP (European Journal of Housing Policy). The Institute is host for a regular Nordic research seminar (IBF/NSBB) and invite regularly guest researchers to the Institute. Also the Institute are heavily involved in the ENHR (European Network for Housing Research), which involves more than 100 research institutions and nearly 1000 individual members all over the world. Affiliated organisations, created by EHNR are APNHR (Asia-Pacific Network for Housing Research), ANHR (Arabic network for Housing Research), SSNHR (Sub-Sahara Network for Housing Research) and LANHR (Latin America Network for Housing Research).

\subsubsection{Iceland}

At Iceland research in building and construction is mainly delivered by the IBRI (Icelandic Building Research Institute). IBRI is an independent research institute which falls under The Ministry of Industry and Commerce. Its main activities are applied research and technical testing for the whole of the building and construction industry. The concrete division is experienced in material technology and durability and has been acknowledged as one of the leading centres in the field of rheology of cement based materials. Emphasis has been on international collaboration and cooperation and IBRI is currently a partner in eleven EU research projects funded in the 5th framework program on RTD. For the last two years IBRI has been in charge of the presidency of ENBRI (European Network of Building Research Institutes).

\subsubsection{Estonia}

In Estonia there are not any specialised research institutions for the building and construction sector. At the Tallinn University of Technology research are carried out with importance for the sector. Especially the Departments for Structural Design, for Building Production and for Environmental Engineering are central for the research in sector. At the Government level The Ministry of Economic Affairs and Transportation (De- 
partment for construction and housing) and The Ministry of Interior (Planning Department - spatial planning) is of importance. Cooperation with other institutions and partners is carried out with Estonia University of Life Science, Estonia Academy of Arts, Tallinn College of Engineering and Estonian Centre for Standardisation.

Participation in international research projects takes place especially in Interreg programs and also in UN-programs.

\subsubsection{Lithuania}

In Lithuania research in building and construction is mainly delivered by the Civil Engineering Faculty at Vilnius Gediminas Technical University. At the Department of Construction, Economics and Real Estate Management (CEPM) researchers participate in more than twenty European (EC) and US projects. Master students from all over Lithuania are studying in three e- learning master programs: Real Estate management, Construction Economics and Internet and Real Estate Business. The master courses are given in three languages (Lithuania, Russia and English). Spheres of current research are Web-based intelligent systems for building and construction, life-long learning and intelligent tutoring systems, development of knowledge base of best practice and knowledge systems for the build and human environment, exchange and developing of new knowledge, electronic collaboration, e-cities, e-government, retrofit, facilities and real estate management, clean built and human environment, integrated building life cycle analysis, total life analysis, modeling and forecasting of build and human environment, sustainable development, innovation management, total quality management, improvement of competitiveness, sustainability, quality and safety of the built environment, fulfillment of user and society needs.

\subsubsection{Finland}

In Finland, VTT Technical Research Centre of Finland, carries out research for the building and construction sector. Competitiveness of enterprises is the key to all major research activities - and a long tradition of Public Private Partnerships in R\&D funding and projects exist. VTT, Helsinki University of Technology and Tampere University of Technology are working on creating a virtual institute in the construction sector. The Ministry of Environment is responsible for buildings and the built environment, but has hardly any R\&D funds available for the sector. The most important performers of research in the public sector are VTT, financed especially from TEKES (the Finnish Funding Agency for Technology and Innovation) and are organized under Ministry of Trade and Industry. A Vision for 2010 is developed by Finland's Real Estate and Construction Cluster in 2000 and TEKES has developed a Technology 
Programme, which has been input for the VTT strategic programme for 2007 to 2011.

Financed by TEKES as well as by other ministries are also other research institutes as the TE-Centres, where research activities in relation to Construction are carried out as well. Under the Ministry of Education are the Universities, where research in Building and Research are seen at Helsinki Universities of Technology and Tampere University of Technology. The role of national borders is disappearing in R\&D policy, and an open platform approach is seen. VTT carry out R\&D in cooperation industrial and business enterprises, organisations, universities and research institutions. VTT participates in many international projects and in the Finnish national R\&D policy, cooperation with technology leaders like US and Japan are above everything else. EU is seen as a domestic market. VTT have had a heavily impact on the pan European ECTP work and participate in significant RP projects, as RoadCon.

\subsubsection{Denmark}

In Denmark the main part of research in building and construction take place in 9 universities and research institutions, including Danish Building Research Institute(SBi), Technological Institute, Aalborg University, Danish Technical University, Copenhagen Business School, Copenhagen University, Roskilde University, The Royal Academy of Fine Arts and Aarhus School of Architecture. Beyond this, research is carried out in private firms.

National R\&D funding is primarily the responsibility of The Danish Research Councils. Further State Governmental Bodies, such as National Agency for Enterprise and Construction, also influence the research activities, especially by (co)funding activities.

Private firms (consulting and architecture, contractors, developers, etc) as well as trade organisations participates in networking activities related to research, and have been active in the national ECTP work. The Danish National Platform is headed by the chairman of the Danish Client Associations.

Danish research institutions participate in international EU FP projects and in the ECTP work at a pan/trans European level as well as in UN programmes. Participation in further international research organisations as ENBRI, CIB, ENHR are especially covered by SBi.

\subsubsection{Norway}

Construction related R\&D in Norway is primarily performed at NTNU (the Norwegian University of Science and technology) and the two major research institutes - SINTEF Buildings and Infrastructure (merger of the previous Norwegian Building Research Institute and the construction 
related parts of SINTEF) and the Norwegian Geotechnical Institute (NGI). Research is, however, also conducted at several smaller institutes e.g. linked to regional university colleges and by several of the more technology active private companies and public authorities. The Norwegian Public Roads Authorities, with their several laboratories and the cement producer Norcem (a company in the Heidelberg Cement Group) have traditionally been among the most active $\mathrm{R} \% \mathrm{D}$ performers outside the institutes.

The Federation of Norwegian Construction Industries, BNL - organizing the majority of Norwegian construction related industry has established an innovation forum with the aim to promote construction R\&D. This forum (FIB) joins together leading representatives from contractors, consultants, building materials producers, branch organizations, building owners/developers, public authorities, research institutes and universities. The FIB also acts as the HLG for the Norwegian technology platform of the ECTP, the secretariat of which is handled by SINTEF Buildings and infrastructure. National R\&D funding is primarily the responsibility of The Norwegian Research Council - who is also the official representative versus the EU research programs. Besides, funding of innovation activities/close to market research programs are handled by Innovation Norway.

\subsubsection{Summary}

Networking is increasingly essential for the research going on in all countries in the Northern Dimension region. The focus in research differs and potentially the research at the different institutes and countries can be complementary to each other. Often diversity in research is not followed by cooperation and there is a tendency for cooperation to take place between partners similar to each other. A need for a special effort to strengthen cooperation can be identified.

A more efficient cooperation between the research institutes to get the advantages of this diversity is seen to have the ability to strengthen the research in all counties independent of the current state and scope of research in each country. Also a will to participate in such a process of collaboration is found.

\subsection{Objective and Action for the programme}

\subsubsection{Objective}

The objective for this part of the Nibcor programme is to provide an overview of the central partners in construction and building research in Northern Dimension as a basis for the Nibcor activities. 


\subsubsection{Action}

Mapping of research partners and their competence covering:

- Public,

- Private,

- Other networks.

The mapping will be done through a survey including barriers for cooperation. 


\section{Research project portfolio preparation}

\subsection{Objective}

The objective for this part of the Nibcor programme is to provide a regional competence and expertise research platform to exchange ideas of projects, to orientate initiatives, to define strategic issues in research to support and facilitate the primary objectives of the action plan.

\subsection{Actions}

At the workshop in Copenhagen several activities for cooperation was identified, all stimulating the process of establishment of specific project cooperation. Common Action is not a problem, once a common need has been identified. The importance of industries willingness to participate and pay was emphasis as a condition for rising additional national funding as well as EU funding. A special task will be to include the industry to participate in the Nibcor activities for cooperation.

Providing a competence and expertise platform is seen as a process which includes the following activities:

- Define main topic areas (confirm and detail - action plan no. 1),

- Dissemination of opportunities for research projects,

- Provide overview for funding opportunities,

- Collect project ideas through joint workshops and brokerage events,

- Integrate and facilitate forming of consortiums for proposals,

- Support proposal writing through focus workshop,

- (Application for funding),

- Workshop on projects results both intermediate and end-results.

The process of project creation is given in figure 2 . 


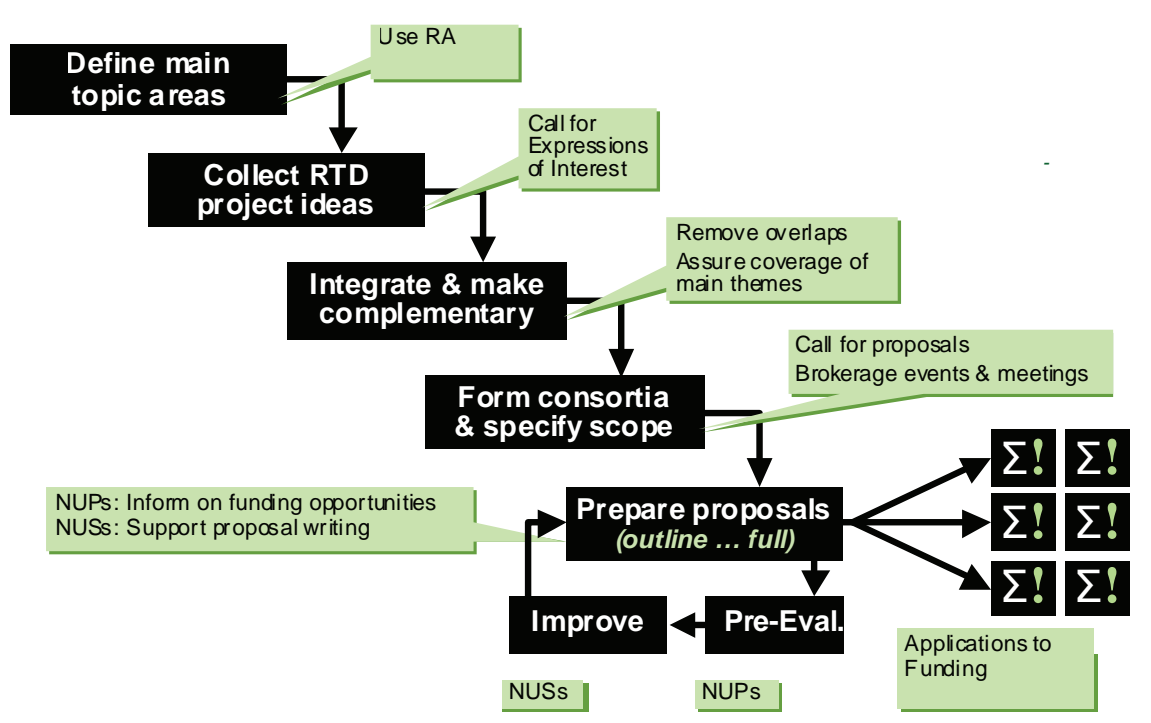

Figure 2. The process of project creation

Especially the upcoming $7^{\text {th }}$ Framework Programme is of interest, but also Regional and national programs may be of interest - as NiCE and the ERABUILD Programme.

Besides, other activities will stimulate the cooperation between the research institutes:

- Exchange of research staff,

- Collaboration with other networks (ENHR, EURA, IFHP, Eurocities, EMF, EHF etc).

For each of the three identified topic areas (see page 9) the figure illustrates the process of combining project ideas and fining partners and funding.

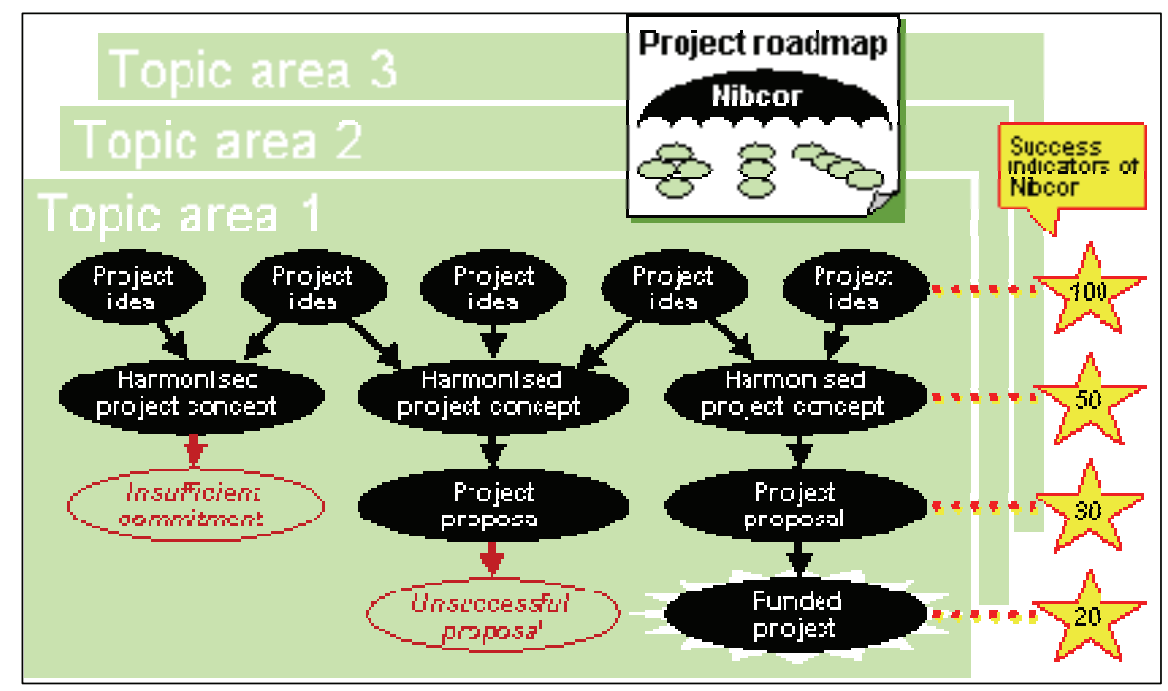

Figure 3. The process of project creation 


\section{Promotion and dissemination}

\subsection{Objective}

To promote and disseminate the activities of Nibcor in order to attract network partners, to explore R\&D topics and to promote projects, to facilitate communication between Nibcor members and to set up/facilitate collaboration between research partners in the region.

\subsection{Actions}

\subsubsection{Introduction}

Activities for communication have mainly been web-based and has included establishment of an address file of research institutes, firms, sector and governmental institutions, a website for the Nibcor project, enewsletters, e-information and sharing sites of research, e-calendar of activities in the Nibcor focus areas, workshop, o.a.

\subsubsection{Promotional actions}

An address file

Central for communication and cooperation has been a database of relevant research institution, researchers, firms in the building and construction sector, governmental, regional and local institutions as well as trade organisations. Firms are seen as important participants in upcoming work with proposal and projects.

\section{Leaflets}

Leaflets have been produced - both in paper and in digital form, informing about the Nordic Region Plan and the Nibcor project. It has been distributed to the research communities, the relevant firms and the national, regional and local bodies.

\section{Nibcor website}

A website has been established. Following functionalities is present:

- Information of the Nordic Region Plan, links to other Nordic Region Initiatives,

- Information of the Nibcor project, 
- Newsletter (also distributed as mail),

- e-sharing of research: Ongoing activities and Results,

- e-sharing of best practice in building and construction,

- e-calendar for main activities of interest for the Nibcor participants, including call for partners, dates for Nibcor workshops, FP7 calls, Intereg calls, ERAbuild calls - as well as other calls for national and regional technology programmes, conferences and meetings in national and international research communities as ENHP, Telecities, etc.

\subsubsection{Workshops and brokerage events}

Four types of workshops were planned to be run: introductory workshops, focus workshops, proposal workshops and project workshops. So far only the introductory workshop and focus workshops has been funded and carried out.

\section{Introductory workshops (completed)}

Introductory workshops are the seen as an brokerage activity, where the program and objectives of the Nordic Region Plan and the Nibcor project is presented. Focus themes are presented and discussed. Other brokerage activities are seen as an integrated part of the process. This will be carried out in parallel with the first Focus Workshop.

Focus workshops (planned)

Focus workshops are established on the themes selected by the Nibcor project as well as on the results from the introductory workshops. The results and the state of the research in the different institutions and firms are presented. Joint partnerships are established both concerning upcoming proposals - and articles and publications from the workshops.

\section{Proposal workshops (planned)}

Proposal workshops are suggested to be established for selected themes in accordance with calls - from FP7, ERABUILD, Interreg, and National and Regional technology programmes e.a. At these workshops important part of the joint work with proposals can be carried out.

\section{Project workshops (planned)}

Project workshops are established in selected themes where support for projects is obtained. Important output will be dissemination of intermediate and end results from the projects.

Exhibitions on research and commercial cooperation/commercial initiatives/drives will be carried out in conjunction with Nibcor workshops and other conferences.

Central in the Nibcor project is the cooperation between research and firms in the building and construction sector. It will be important to let 
the results from Nibcor projects as well as from the participating commercial partners be shown in the different countries and markets, like information about different cultures, workplace regulations, housing regulations, best practice, products etc.

\section{Study visits and guest researchers}

Study visits was planned to be established, often in relation the workshops. Guest researchers and guest staff-members at firms will be an important an effective mean to increase cooperation and sharing of knowledge about markets, regulations and research.

These activities are established especially to support actors in the network without other funding possibilities.

Besides support to participation in the introductory workshop, no study visits have been carried out, because of lacking funding. 



\section{Phase 2: Workshop and Nibcor Home site}

\subsection{Objective}

The objective for phase 2 was to establish a regional network for joint R\&D in Building and Construction, that can contribute to identification of research challenges (of common interest), dissemination of knowledge and to strengthen the research co-operation in the region. Hereby will be provided a regional competence and expertise research platform, to exchange ideas of projects, to orientate of initiatives, to define strategic issues in research to support and facilitate the primary objectives of the Action Plan.

\subsection{Activities}

Two main activities have been carried out:

- Promotion and dissemination,

- Workshop and brokerage event.

\subsubsection{Promotion and dissemination}

A website has been established as the central element of promotion and dissemination. It is located on the address: www.sbi.dk/nibcor.

At the website all central information about the project has been disseminated, like the Nordic Action Plan, the Nibcor Report Phase 1, information on funding opportunities, and link to Calls.

Central on the site has been an invitation to and information about the Phase 2 Workshop in Helsingore, Denmark, $15^{\text {th }}$ and $16^{\text {th }}$ of January, 2007 (see Appendix 2). The invitation was distributed through the Nibcor Working Group as well

After the workshop the result and presentations has been disseminated through the website. On the site more than ten presentations are shown. Themes and ideas for specific research and development projects are identified and a list of potential members of a $R \& D$ network is identified among the participants of the workshop. 


\subsubsection{Nibcor workshop in Helsingore}

The workshop was addressed to potential participants in upcoming consortia from research institutions and firms from the Building and Construction sector. Participation was free. At the workshop 30 researchers, firm representatives and research administrators participated (see Appendix 2).

The workshop had two main slots - funding opportunities and brokerage event

During the first day the focus was on Research Funding possibilities and on experiences for establishing and carrying out international joint research projects. The $7^{\text {th }}$ Framework Programme was presented with emphasis on the first call, which had just been released. Further experiences from Research projects and from building consortia in the FP6 was presented. The experiences from and further plans with the activities from the European Construction Platform was described, and experiences from one of the national platform was reported (Lithuania). Further funding opportunities with ERABUILD, EUREKABUILD and NICe were presented at the Workshop.

Following, a Brokerage Event took place around the three themes identified in Nibcor phase 1:

- Meeting Client and Users requirement;

- Transformation of the Construction Sector;

- Digital Built Environment.

In each group the themes was presented by the Theme Group Convenor. Participants made short presentations of their ideas for further research, interest and background in research or industry. This was followed by a discussion of possible project ideas, funding possibilities, possible participants, missing partners, contact persons. Suggestions were presented in a project template or as power point presentations. The brokerage event concluded with a grouping around a number of consortia ideas under each of three themes with a short description, coordinator for the idea and interested partners as well as possible funding opportunities.

During the brokerage event more than 17 project ideas and contact persons were identified covering the three themes:

- Meeting client and users requirement -3 project ideas,

- Transformation of the Construction Sector -10 project ideas,

- Digital Built environment -4 project ideas.

The presentations and ideas can be found on the Nibcor Website (see presentation 10 and 11 - and Themes). 


\subsubsection{Meeting in the Working Group (Tuesday, 16th, 2007)}

At the meeting the experiences from the workshop was discussed. Everybody was satisfied with the outcome of the workshop. Information about funding, ideas for projects - and contact between stakeholders in potential upcoming projects was established. Especially for stakeholders who so far had not been deeply involved in the ECTP work, the workshop had been a gateway to access to other networks for joint project.

The following recommendations were given for future activities:

- Enforce the contact to the Polish representatives and industry in general;

- Explore interest for cooperation with National Technology Platform for development of a common building research agenda, but there might be 2 parts industry focus and society/government focus (Nibcor);

- Establish Nibcor phase 3 with the purpose of having more brokerage events and facilitate project proposals from the first Workshop and thereby supporting regional research in identified areas.

\subsection{Output from Phase 2}

A network of stakeholders in research, in the industry and in governmental research bodies, especially in the Nordic Region has been established. More the 14 project ideas and contact persons have been identified and can be seen at the Nibcor website. The project ideas are covering all of the three themes.

Bringing in partners from the Nibcor network has taken place in the building up of consortia for applications for in FP7, NICe etc. Some joint research project has subsequent been formulated and are searching for funding.

Stakeholders in Nibcor has during the summer 2007, continued been involved in RP7 proposals as well as in work related to NICe Calls. For example has Nibcor made en EOI for a NICe Call on Support for Innovative Construction (see Appendix 3) It was accepted and work with a full proposal in coordination with NCTP and Norconstruct did take place, but was abounded when the other partners decided to go for themselves. A proposal for the Nibcor phase three was worked out (see Appendix 4). Also there have been contacts about cooperation in projects about Standardisation from stakeholders in the Baltic Area.

None Nibcor Consortium has been reported established. This is in accordance with the postponement of the Third Phase, which especially had the scope of facilitating activities for establishment of consortia's, for the work with proposals and for the work further on with projects. 



\section{Organisation and Management}

\subsection{Objective}

The objective for this part is to manage successfully the Nibcor programme as described in the previous part of the action plan.

\subsection{Actions}

The organisational structure of the Nibcor programme is given below.

\subsubsection{Working Group and Advisory Panel}

The Working Group is central in the project. The Group will be a central element in the national research communities concerning international cooperation and production of international proposals.

The Group will obtain significant knowledge about the international dimension concerning the building and construction sector in all the focus areas which the Nibcor project shall cover. The Group will be the Advisory Panel on research in construction and building on national, regional and European level and advise relevant decision makers.

\subsubsection{Focus Groups, Proposal Teams and Projects}

For each of the Focus Themes a workshop was planned to be organised. So far no funding has been given and no Focus Group workshop has been completed.

The participants were planned to function as Focus Groups. For some of the Focus Groups, Teams for making proposals will be established. Key persons in the Focus groups and in the Proposal teams may be members of the Working Group, the Secretariat or the participating researchers. Some of the Proposals will result in supported projects, having projects leaders, WP leader etc, all financed by their funding programmes. Project Workshops will be established organised by the secretariat in cooperation with the project, the Steering Group and the relevant Working Group Members. 


\subsubsection{Steering Group}

The Steering Group meets, coordinates and adjusts the activities and reports to the Northern Dimension Region Programme Coordinator as to the existing Steering Group.

\subsubsection{Secretariat}

The Secretariat will continue to be located at SBi.

\subsubsection{Project leader}

Lone Moeller Soerensen,

Director, SBi, Denmark.

\subsubsection{Contact to international institutions}

Important will be the synergy which shall be established in corporation with existing international Funds, programmes and networks.

Contact to: FP 7, ERABUILD, ENHR, ENBRI, ECTP, Nordic innovation Centre and TeleCITIES. 


\section{Time schedule}

\subsection{Time schedule}

\begin{tabular}{ll}
\hline Completed & \\
\hline $\begin{array}{l}\text { Start of project: } \\
\text { Survey, address files etc. }\end{array}$ & November 2006 \\
Website & Nov - Dec 2006 \\
Newsletter, e- sharing & Continuing \\
Leaflets & Dec. 2006 \\
Workshops & Jan. 2007 \\
Introductory Workshop (1) & \\
\hline Planned & \\
\hline $\begin{array}{l}\text { Focus Workshops (2) } \\
\text { Proposal Workshops (4) }\end{array}$ & Jan. 2007; Jan 2008 \\
Project Workshops (2) & March 2007, Oct 2007; Febr. 2008; June 2008 \\
$\begin{array}{l}\text { Coordination Workshops (2) } \\
\text { (Working group) parallel withFocus Workshops }\end{array}$ & March 2008; Nov 2008 \\
$\begin{array}{l}\text { Exhibitions } \\
\text { (parallel with Project Workshops) (2) } \\
\text { Study visits }\end{array}$ & Febr. 2007; Jan. 2008 \\
Guest Staff/researcher & March 2008; Nov. 2008 \\
\hline
\end{tabular}





\section{Dansk resumé}

Høje priser, lav konkurrence og orientering mod lokale markeder karakteriserer byggesektoren i dag. Det antages, at en mere transparent og harmoniseret byggemarked i den nordiske region vil forbedre de enkelte markeder i regionen og reducere huspriserne via en reduktion af byggeomkostningerne. Dette er formålet med handlingsplanen 'Increased exchange in the building sector between countries in the Northern Dimension region' under Nordic Council of Ministers. Den nordiske region dækker Danmark, Estland, Finland, Island, Letland, Litauen, Norge, Polen og Sverige.

Samarbejde og udveksling af viden er vigtige præmisser for at facilitere handel og mobilitet og stimulere tværnationale byggeaktiviteter. Forskning og udvikling spiller en vigtig rolle i denne kontekst, idet de bidrager med undersøgelser, delt viden og udvikling af ny viden.

Et større og mere transparent marked vil give nye muligheder for forskning og udvikling af processer, produkter og services, og dermed både give nye muligheder for øget produktivitet i byggesektoren, såvel som forbedre forståelsen og opfyldelsen af bruger- og samfundskrav til bygninger og det byggede miljø.

Dette projekt, Nibcor, er tænkt som et projekt med to faser. Denne rapport beskriver resultaterne af den første fase, der har til formål at udvikle et samarbejdsprogram for et netværk til fælles forskning og udvikling indenfor handlingsplanens rammer.

Der eksisterer et antal regionale og europæiske forskningsinitiativer vedrørende netværk og støtte via forskningsprogrammer i byggesektoren. Selvom visse af disse programmer har elementer, der kunne understøtte handlingsplanen, er der ingen af disse programmer, der har samme forskningsmæssige formål, som denne handlingsplan.

Derfor er udviklingen og etableringen af et samarbejdsprogram for et regionalt netværk for fælles forskning og udvikling en central del af handlingsplanen. Samarbejde med relevante netværk og støtteprogrammer vil dog være en vigtig del af Nibcor projektet. Et fælles forsknings- og udviklingsnetværk i regionen vil derudover styrke forskningen i regionen og dermed udgøre en frugtbar platform for indflydelse på og mulighed for støtte i forhold til de regionale og europæiske forskningsprogrammer. 
Via en workshop og korrespondance med en national repræsentant fra hvert land i den nordiske region blev tre forskningsområder udpeget som centrale fokusområder for Nibcor:

- Opfyldelsen af kunde- og brugerkrav,

- Transformationen af byggesektoren,

- Det digitale byggede miljø.

Disse blev valgt som vigtige forskningsområder i relation til reduktion af barriererne for tværnational udveksling af forskning, viden og byggeaktiviteter.

Endvidere har en indledende scanning af forskningspartnere i den nordiske region givet et foreløbigt overblik over forskningspartnerne. Dette viser et potentiale for øget forsknings- og udviklingssamarbejde, for såvel samarbejdspartnere med en lignende forskningskompetencer som med komplementære forskningskompetencer.

Formålet med fase 2 i dette projekt er, at etablere et regionalt netværk for fælles forskning og udvikling indenfor byggeriet, der dækker de forskningsområder, handlingsplanen udstikker. Denne rapport identificerer en handlingsplan for etableringen af et regionalt netværk for fælles forskning og udvikling, og fortæller om de initiativer, der er gennemført, først og fremmest en international workshop afholdt i Helsingør den 15. og den 16. januar 2007 (se bilag 2), og en digital kommunikationsplatform i form af en hjemmeside for projektet (se www.sbi.dk/nibcor).

I bilag (bilag 3 og 4) er endvidere vedlagt beskrivelse af en fase 3, der har til formål at igangsætte egentlige forsknings- og udviklingsaktiviteter med et kommercielt potentiale for byggesektoren i de involverede lande. 


\section{Appendix 1}

\section{National input on research for Nibcor from participating countries}

As a central part of the initial phase of the project a workshop was held in Copenhagen, June $26^{\text {th }} 2006$ with national representative of the participating countries of the Northern Dimension Region.

The following research areas were proposed as topic areas for the Nibcor programme.

\section{Sweden}

- Urbanisation, suburbanisation and urban sprawl

- Mobility and demographic changes

- Housing wealth and demand studies

- Building cost analysis + management studies

- Costs of building and planning regulations

- Affordability and sustainability issues

- Segregation and integration - social cohesion

- Financial integration and guarantee systems

- Methods-GIS, regression methods, monitoring etc.

Iceland

- Sustainability

- Durability/rehability

- Housing cost - competition

- Building technology

- Construction process

- IT in construction

Estonia

- Impact of shadow market/economy

- Effectiveness of supervision (procedures!)

- Implementation of the new procurement methods (BOOT, BOT)

- Possibilities of introducing different guarantees for the clients/residents 


\section{Lithuania}

- Exchange and developing of new knowledge,

- Development of knowledge base of best practice and knowledge systems for the build and human environment,

- Harmonisation of building regulations and legislation,

- Free mobility of labour and cross-border construction activities,

- Fulfilment of user and society needs,-

- Improvement of competitiveness, sustainability, quality and safety of the built environment,

- Technological development,

- Internal e-integration in the construction sector,

- Electronic collaboration,

- Retrofit, refurbishment and facilities management,

- Clean built and human environment,

- Transparent markets in terms of housing demand, economics and demography,

- Development and support of a single European market in the building and construction industry,

- Life-long learning and intelligent tutoring systems,

- Web-based intelligent systems for building and construction,

- Integrated life cycle analysis,-

- Total life analysis, modelling and forecasting of build and human environment

- New materials and design solutions,

- New opportunities for increasing productivity in construction and building sector,

- Single regional market,

- Sustainable development

Finland

Digital Built Environment:

- New integrated construction processes with dynamic supply networks

- Information management over the lifetime of the products and systems in the built environment

- Integrated product models: interoperability, simulation and visualization

- Eco efficient, healthy and safe environment for people and businesses

- ICT-based services for mobile users; telematic services for transport of people and goods

- Ubiquitous environments: sensor networks combined with adaptable materials. 
Functional and Nano materials:

- Surface functionalisation, adaptive and active materials, hybrid materials

- Modification of materials by nanotechnology

- Bio nano materials and biosensors

- Nano electronics and photonics, polymer nano composites for printable electronics.

Technology in the Community:

- Detection, identification, protection and assessment methods for safety and security of people, critical infrastructures, industrial production systems

- Energy-and eco efficiency and lifetime management of the built environment, technologies for integrated management of indoor environment

- Transport and traffic systems based on user requirements: services, products, and safety solutions; development of concepts and assessment methods.

Applied materials:

- Materials for machinery, buildings and consumer products: new and modified materials and methods to bond materials into composites and structural systems

- New fibre-based products; added value wooden products

- Performance of products and structures under long-term or extreme exposures.

\section{Denmark}

Meeting clients and users requirements:

- Understanding and defining users future needs in a business perspective

- Value-based procurement

- Client leadership/clients as change agents

- Benchmarking, best practice and user feedback

- Make market information and "rules of the game" accessible to potential actors. 
Sustainability:

- New technologies, concepts and materials for efficient and clean buildings and urban areas by an integrated design approach (indoor environment, design, functionality, price)

- Remove barriers in regulations as a basis for deliberations on possible harmonization -identification \& research consequences on possible changes

- High added value construction materials.

Transformation of the construction sector:

- New integrated process (partners, industrialization, productivity, claims by delivery)

- ICT for construction-process and products

- Competence requirements and mobility of resources

- Legal barriers in public procurement and for public-private partnerships etc.

Norway

- Climate change - consequences and precautions for the built environment

- Under-ground technology

- Increase energy efficiency in buildings

- universal design of the built environment

- Concrete Innovation centre - COIN at SINTEF Byggforsk/NTNU

- Advanced cementing materials

- Improved construction technique

- Innovative construction concepts

- Multifunctional design.

Based on the workshop discussions, topics which contribute to reducing barriers or knowledge of barriers for the cross-border transfer of research, knowledge and building activities were decided to be given priority. 


\section{Appendix 2.}

Nibcor Workshop in Helsingore, 15-16 ${ }^{\text {th }}$ of January, 2007

\begin{tabular}{|c|c|}
\hline Program & Monday $15^{\text {th }}$ of January, 2007 \\
\hline 11.00 & Arrival and Registration \\
\hline 12.00 & Lunch \\
\hline 13.00 & $\begin{array}{l}\text { Welcome, Background and Objectives } \\
\text { Lone Moeller Soerensen, Nibcor, SBi }\end{array}$ \\
\hline 13.20 & $\begin{array}{l}\text { FP7. Opportunities for research in Construction } \\
\text { European Commission }\end{array}$ \\
\hline 14.00 & $\begin{array}{l}\text { Building Consortia and doing Integrated Project } \\
\text { Experiences from an RP } 6 \text { project InPro: Open Information } \\
\text { Environment for Knowledge-based Collaborative Processes } \\
\text { throughout the Lifecycle of a Building } \\
\text { Stefan Lindsköld, NCC R\&D }\end{array}$ \\
\hline 14.25 & $\begin{array}{l}\text { ECTP } \\
\text { Matti Kokkala, VTT }\end{array}$ \\
\hline 14.50 & $\begin{array}{l}\text { NTP }-L T \\
\text { Gintaras Grachauskas, LDRMT }\end{array}$ \\
\hline \multicolumn{2}{|l|}{ Pause } \\
\hline 15.30 & $\begin{array}{l}\text { ERABUILD } \\
\text { Gustav Christoffer Jensen, Ebst }\end{array}$ \\
\hline 16.00 & $\begin{array}{l}\text { EUREKABUILD } \\
\text { Svein Willy Danielsen, SINTEF }\end{array}$ \\
\hline 16. 30 & $\begin{array}{l}\text { NICe } \\
\text { Mads Peter Schreiber, Nordic InnovationCenter, Norway }\end{array}$ \\
\hline \multicolumn{2}{|c|}{ Pause (in Theme Group Rooms) } \\
\hline 17.00 & $\begin{array}{l}\text { Brokerage event - in parallel in Theme Groups (see below) } \\
\text { - Theme 1: Meeting Client and Users Requirement } \\
\text { - Theme 2: Transformation of the Construction Sector } \\
\text { - Theme 3: Digital Built Environment }\end{array}$ \\
\hline & $\begin{array}{l}\text { In each Theme Group: } \\
\text { - Introduction: Presentation of Theme (Theme Group Conve- } \\
\text { nor (TGC)) } \\
\text { - Presentation of research, ideas and suggestions for re- } \\
\text { search tasks (All, TGC as facilitator). Each participant makes } \\
\text { a short presentation of their interest and background in } \\
\text { research or industry. } \\
\text { - Discussion of potential joint projects and consortiums (All, } \\
\text { TGC as facilitator) (see below) }\end{array}$ \\
\hline 18.00 & Dinner \\
\hline 21.00 & Brokerage event (continued) \\
\hline
\end{tabular}




\begin{tabular}{ll}
\hline Program & Tuesday 16th of January, 2007 \\
\hline 09.00 & Brokerage event (continued) (in parallel sessions in Theme \\
& Groups) (see below) \\
& Discussion continued \\
& Plan for realisation of joint R\&D projects \\
& Concluding debate. How to bring the work further on. \\
11.00 & Experiences from the theme-groups (TGC and reporter) \\
& Concluding remarks (Lone Moeller Soerensen) \\
12.00 & Lunch and Departure \\
\hline
\end{tabular}

The Brokerage Sessions in Theme Groups

Following items should be debated and results should be taken down:

\begin{tabular}{ll}
\hline Monday & Focus on \\
\hline & Interim list on project ideas and themes \\
& Potential partners \\
& Identification of Consortia Group Leaders \\
& Missing actors \\
& Funding possibilities \\
\hline Tuesday & Focus on \\
\hline & Barriers \\
& Plan for Realisation of further joint projects \\
& New meetings \\
& Nibcor Contributions \\
& Website: Presentation of Themes \\
\hline
\end{tabular}


List of participants

\begin{tabular}{|c|c|c|}
\hline Name & Organisation & Country \\
\hline Andris Vulans & LAU & Latvia \\
\hline Anne Beim & Cinark & Denmark \\
\hline Arturas Kaklauskas & VGTU & Lithuania \\
\hline Bengt Nyman & $\mathrm{NCM}$ & Sweden \\
\hline Björn Marteinsson & IBRI & Iceland \\
\hline Christian Koch & DTU & Denmark \\
\hline Eyjolfur Bjarnason & Aoll & Iceland \\
\hline Gintaras Grachauskas & LDRMT & Lithuania \\
\hline Gudni Gudnason & IBRI & Iceland \\
\hline Gustav Christoffer Jensen & Ebst & Denmark \\
\hline Hakon Olafsson & IBRI & Iceland \\
\hline Harri Kemppainen & Isover & Finland \\
\hline Irene Lill & Tallin Universitet & Estonia \\
\hline Janis Kreilis & LAU & Latvia \\
\hline Jonas Ragaukas & LREDA & Lithuania \\
\hline Karina Sandfeld Jensen & $\mathrm{SBi}$ & Denmark \\
\hline Kjeld Svidt & AAU & Denmark \\
\hline Kresten Storgaard & $\mathrm{SBi}$ & Denmark \\
\hline Lone Møller Sørensen & $\mathrm{SBi}$ & Denmark \\
\hline Mads Peter Schreiber & $\mathrm{NICe}$ & Norway \\
\hline Marianne Forman & $\mathrm{SBi}$ & Denmark \\
\hline Mats Wilhelmsson & KTH & Sweden \\
\hline Matti Kokkala & VTT & Finland \\
\hline Per Christianson (AAU) & AAU & Denmark \\
\hline Roode Lias & Tallin University & Estonia \\
\hline Rune Wigren & Uppsala University & Sweden \\
\hline Silvija Strausa & LAU & Latvia \\
\hline Stefan Lindsköld & NCC & Sweden \\
\hline Svein Willy Danielsen & SINTEF & Norway \\
\hline Vincentas Stragys & VGTU & Lithuania \\
\hline
\end{tabular}





\section{Appendix 3.}

\section{EOI for NICe Call: Support for Innovative Construction}

Nibcor - a Network for Strategic Partnerships in Research, Construction, Expanding Technologies and Economies

\section{Problem description}

The Construction Sector in the Nordic Countries has a potential for being of strategic importance for the Nordic Economies. It is a sector where other expanding technologies and economies and services will be used, a challenging opportunity for collaboration for developing future solutions.

In the Nordic Council of Ministers an Action Plan "Increased exchange in the Building Sector between countries in the Northern Dimension Region" was formulated. The Northern Dimension Region covers the five Nordic Countries and Latvia, Estonia, Lithuania and Poland. A project, Nibcor, was established to support networking and formulation of research proposal to international projects between construction and research. The two first stages were carried out successfully. The result is a strong base of networks between significant research institutions, firms and national bodies.

The Nibcor network has a potential to be developed further on, to a network platform for strategic partnerships between R\&D institutions and firms, The Construction Sector and Expanding Technologies and Economies in other sectors, for which the built environment can be seen as a test-bed for developing solutions for future services and products. The users and stakeholders of the built environment in the Nordic Countries might be seen as advanced users, with high demand for functional solutions supporting life and activities in homes, offices and institutions. Strategic partnerships might be established through networking, building up trust between the stakeholders, and resulting in potentially commercial results, products and services.

\section{Objective}

- To establish strategic partnerships between R\&D institutions, firms in the construction sector, firms outside the construction sector (ICT, Health and Comfort, Energy and Sustainability, Living, home and Lifestyle);

- To strengthen competitiveness for firms in the strategic partnerships;

- To create openness for cross national cooperation between firms, research and funding bodies; 
- To create project consortia for the strategic partnerships targeting Calls (RP7, ERA-build, a.o);

- To support granted projects through dissemination and extended networking of result and through exhibition of results.

\section{Participants}

The established Nibcor Working Group will be core participants, they include:

- SBi -Danish Building and Research Institute, Denmark,

- IBRI - Icelandic Building Research Institute, Iceland,

- Tallin University of Technology, Estonia,

- Vilnius Gediminas Technical University, Lituania,

- VTT Technical Research Centre of Finland, Finland,

- SINTEF Bygforsk, Norge,

- ITB, Poland,

- Uppsala University, Sweden.

Further firms' representatives from already established theme groups are included.

The network will be extended especially with representatives from firms and R\&D institutions in ICT, Health and Comfort, Energy and Sustainability, Home and Lifestyle.

\section{Method}

- Workshops for consortia establishment for research proposals for RP7 and other Calls (five through 2007-2009),

- Workshops for proposal preparation (five, 2007-2009),

- Workshops for project dissemination and extended networking ( two, 2008,2009),

- Exhibitions for results and solutions for industry, design and research,

- Virtual networking and dissemination through the Nibcor website,

- Leaflets, report and articles.

Which Organisations will use the Project outcome?

The Construction industry (the value chain, especially the Building Material and Component Industries, Designers, Consultants, Constructors, Clients and FM drivers), The ICT sector (embedded Technology, mobile Technologies, nD Designing), the Health and Comfort Sector, Sustainability and Energy sector, Home and lifestyle Sector as well as research and Development firms and institutions in the extended Nordic Region. 


\begin{tabular}{|c|c|c|}
\hline Budget (in NOK) & Funding & Self-financed \\
\hline $\begin{array}{l}\text { Theme/call workshops } \\
(5 ; 2007-2009) \\
\text { ( } 30 \text { personer }- \text { one day x } 2.000 \mathrm{kr}=30.000) \\
\text { Wages: } 30 \text { persons } \times 40 \text { hours } \text { x } 900 \mathrm{kr}\end{array}$ & 150.000 & 1.080 .000 \\
\hline $\begin{array}{l}\text { Proposal workshops } \\
(5 ; 2007-2009) \\
(10 \text { persons }- \text { two days } \times 2.000 \mathrm{kr}) \\
\text { Wages ( } 10 \text { persons } \times 12 \text { hours } \times 900 \mathrm{kr} \text { at five times) }\end{array}$ & 200.000 & 600.000 \\
\hline $\begin{array}{l}\text { Project workshops/dissemination } \\
(2 ; 2008,2009) \\
(10 \text { persons } \times 2 \text { projects } \times \text { two times } \times 2.000+\text { cost }) \\
\text { Wages }(10 \text { pers. } \times 15 \text { hours } \times 900 \mathrm{kr})\end{array}$ & 100.000 & 135.000 \\
\hline $\begin{array}{l}\text { Exhibition } \\
(2 ; 2008,2009) \\
\text { (Wages } 5 \text { persons } \times \text { two times } \times 8 \text { hours } \times 900 \mathrm{kr} \text { ) }\end{array}$ & 90.000 & 36.000 \\
\hline Study visits and travel & 120.000 & \\
\hline $\begin{array}{l}\text { Guest researchers } \\
\text { (support to travel, board and lodging) } \\
\text { Wages (10 persons } \times 40 \text { hours } \times 500 \mathrm{kr} \text { ) }\end{array}$ & 140.000 & 200.000 \\
\hline $\begin{array}{l}\text { Working Group } \\
\text { Wages (10 persons x } 900 \mathrm{kr} \times 60 \text { hours) } \\
\text { Stay and Travel }\end{array}$ & $\begin{array}{l}270.000 \\
140.000\end{array}$ & 270.000 \\
\hline $\begin{array}{l}\text { Steering Group } \\
\text { Wages ( } 3 \text { persons } \times 900 \text { kr. } \times 10 \text { hours) } \\
\text { Cost and travel }\end{array}$ & $\begin{array}{l}27.000 \\
30.000\end{array}$ & \\
\hline Secretariat (250 hours x 900 kr) & 225.000 & \\
\hline Web site, newsletter, e-sharing & 60.000 & \\
\hline Leaflets, publications & 100.000 & \\
\hline Address files & 20.000 & \\
\hline Total & 1.672 .000 & 2.321 .000 \\
\hline In total & & 3.993 .000 \\
\hline
\end{tabular}





\section{Appendix 4.}

\section{Full proposal for the NICe Call: Support for Innovative Construction}

\section{Project title}

Network for Strategic Partnerships in Construction, Research and Policy System in the Northern Region - SpiCorps:

- Project start: 1.1.2008

- Project end: 31.12.2010

\section{Problem description}

The Construction Sector in the Nordic Countries has a potential for being of strategic importance for the Nordic Economies. Other expanding technologies and economies and services will be used in the built environment eg. ICT, Health and Comfort, Sustainability and Energy, Home, Experience and Lifestyle sectors. The users and stakeholders of the built environment in the Nordic Countries might be seen as advanced users, with a high demand for functional solutions supporting life and activities in homes, offices and institutions, a challenging opportunity for developing future innovative and competitive solutions through collaboration. Construction is heavily based on local experience and tradition - a challenge in the increasing internationalisation even Construction is facing. However the Nordic Countries and the Baltic Countries and Poland (hereafter named the Northern Region) has a Construction sector which in many ways do complement its other with a potential for more efficient use of know-how, design, components, materials and work forces on all levels, across countries in the Northern Region. Combined with a Nordic tradition for strong cooperation in the sector, now gradually expanding to include partners in the Northern Dimension and thereby expanding the local Northern Market, this represents a strong base for strengthening the innovation and competitiveness of the sector in the region. As envisage by EC, collaboration between significant stakeholders in business, R\&D and governmental systems in a regional research and innovation clusters represents a powerful tool in European and Global competition. It is the hypothesis of the project that collaboration between firms, research communities and policy bodies in the Northern Region in flexible strategic partnerships may result in world leading services and products. These 
strategic partnerships will constitute a further economic growth in the region. It is further the hypothesis that such partnerships most effectively will be established through a process of networking activities in workshops where themes for collaboration can be identified, potential partners contacted, and where trust between the members of potential consortia may evolve. Today the situation is characterized by minor cooperation between construction and other businesses. In Construction the focus is mostly on developing new technologies to means for more efficiency and productivity in the sector itself. In High Technologies, Construction is seen as a low tech sector and as a marginal market. The potential for effective strategic collaboration between research, Construction and the policy bodies are grounded in a tradition for cooperation in the Nordic Countries. In Construction some of the big firms have a pan-Nordic base. Similarities in culture, traditions, value, as well as conditions determined by climate, create a fruitful base for future strategic cooperation. Today collaboration in Construction across the countries in the Northern Region is especially restricted by missing knowledge of potential and possibilities for co-projects as well as regulations to construction and labour.

In the Nordic Council of Ministers an Action Plan "Increased exchange in the Building Sector between countries in the Northern Dimension Region" was formulated. A project, Nibcor, was established to support networking and formulation of research proposal to international projects between construction and research. The two first stages were carried out successfully. The result is a strong base of networks between significant research institutions, firms and national bodies. This Nibcor network has the potential to be developed further on, to a platform for strategic partnerships between R\&D institutions and firms in Construction and Expanding Technologies and Economies, for which the built environment can be seen as a test-bed for developing solutions for future services and products.

\section{Summary}

Strategic collaboration between firms in Construction, and firms in expanding technologies and economies, research institutions and policy bodies in the extended Northern Region (the Nordic Countries, the Baltic Countries and Poland) have a potential for developing world leading products in a globalized market. Today this potential is far from being used. Barriers in differences in tradition, collaboration and missing knowledge of possibilities and partners in the extended Northern Region are hindering forces. The Northern Region have a structure of complementarities, especially in Construction, which may heighten research and strengthen the businesses in all countries and open up for a globalised market. Also the diversity in economic and social structure may widen up the access to FP 7 funding. The experiences and institutional structures for collabora- 
tion in the Nordic Countries may be used to develop these potential to real economic growth based on user values, effective collaboration.

The projects connection to other projects financed by the Nordic Innovation Centre

Several of the NICe focus areas are highly relevant for the SpiCorps Network like Innovative Construction, Creative Technologies, Environmental Technology, Micro- and Nano Technology. In the SpiCorps terminology these focus areas represent important segments in the expanding technologies and economies. Also stakeholders in User driven Innovation and the NICe-EU project will be contacted to obtain reciprocal benefit, eventually through participation in the network activities.

The proposed network, SpiCorps has a clear connection to the new project, Norconstruct, with its emphasis on network between the policy bodies. Cooperation between the proposed network and Norconstruct is aimed at and prepared in the preparation stage and through personal links of the two projects.

Similar a close cooperation is planned with the technology platforms in the Nordic countries, NCTP. Seen in the SpiCorps perspective a fruitful collaboration between these three platforms could be established where Norconstruct especially had focus on the policy bodies, NCTP the firms in construction, and the SpiCorps the research communities.

In addition SpiCorps has a strong link to the European Construction Technology Platform, ECTP through Nibcor coordinator, who is member of the steering group of the ECTP as well as Nibcor's members being active in the ECTP and in the national construction technology platform.

SpiCorps would further function as a gateway between the construction sector (firms, research and policy bodies) and other strategic relevant spheres in expanding technologies and economies, as well as to stakeholders and markets in the extended Northern Region.

\section{Relevance of Nordic Business Sector}

The construction is often characterized as a local market with a lack of transparency which hinders increased development of innovative and competitive solutions for the international marked. Strategic collaboration between firms in the construction sector and the expanding economies in ICT, the new services, health and the entertainment sector offers opportunities for developing world leading solutions for a European and global market, both for the construction sector and for the collaborating businesses. Users in the Nordic Countries may be seen as advanced users, meaning users with high demands for solutions supporting human values in family life, at work or at institutions. Climate defines efficient design and constructing and high price on labour set up conditions for efficiency 
in production. The built environment may be seen a test-bed for technologies and businesses in ICT, Health and Comfort, energy and Environment and I Home, lifestyle and experience economies. Hereby strategic partnerships may be of benefit not only for the construction sector, but for the sectors representing expanding technologies and economies. In Construction potential benefits will occur not only in the resulting end product, but throughout the whole value chain from design, consultancy, process, components, materials, to facilities management. The proposed network is aimed at creating a Northern construction marked for innovative and competitive solutions, which serves as a strong basis for the international marked.

\section{Benefit for society}

Improved co-operation between countries and stakeholders in the Northern Dimension region through strategic networks will provide an increasing and more transparent building and construction sector and thereby contribute to a more competitive sector resulting in reduced costs and building prices as well as increased value for the end user and society. This will serve as a strong platform for strengthening the position of the sector on the European and international marked. With the large size of construction sector and the huge impact of the built environment on the individual person and society, an improved performance of the sector will have an immense impact on the economy and value for society in general and the individual person.

Better knowledge to national standards and regulations in the Northern Region will widen the possibilities of using experiences, materials and labour across the region. This creates improved functionality and performance of the products and systems as well as increased process efficiency and thereby creating increased value for end users and society in general in the Northern Region

\section{Objective}

The overall objective is to increase innovation and competitiveness of the Northern construction sector and the relevant expanding technologies and economies on the Northern, European and international market through regional research and innovation clusters for strategic partnerships. Further the objective is to support development of strong research groups in the Northern Region which are competitive on the European and Global market. Thematically the clusters/partnerships will initially focus on three topics, which were defined through the Nibcor project and which are in line with the Construction for Humans approach of NICe. The topics are Meeting Client and Users Requirement, Transformation of the Construction Sector, and the Digital Build Environment. In the first phase of the 
project this topics are extended to topics, selected with focus on what the construction sector can contribute to in other sectors of technologies and expanding economies.

The overall objectives will be reached through:

- Networking activities in workshops with the aim of establish consortia for proposals, projects and commercial products and services;

- Theme Workshops where themes are selected in accordance with funding opportunities (e.g. FP7, NICe, ERA-Build, National Funding);

- Proposal Workshops where consortia created in the network gets the opportunity to prepare proposals;

- Project Workshops where the consortia get opportunities for dissemination and knowledge sharing with the NICe community, the business sectors, research communities and relevant policy bodies, concerning results, experiences, future strategic collaborations and marketing.

\section{Dissemination and coordination}

- Exhibitions are established in parallel with project workshops;

- A website will be developed (adjustment of the Nibcor-site).

\section{Summary}

The overall objective is to increase innovation and competitiveness of the Northern construction sector and relevant expanding technologies and economies on the Northern, European and international market through regional research and innovation clusters for strategic partnerships. The objective will be reached through strategic partnerships, project consortia targeting research calls, dissemination for granted projects as well as contact to relevant policy and funding bodies.

\section{Project ambition in a European/international context}

The use of the build environment in the Northern Region Countries may be seen as offering a platform of extreme use. Both concerning high demand to technical solutions based on climate and weather conditions, high demand to functional solutions supporting family life, working life, services and experiences, and high demand to architectural and cultural dimensions.

It is the ambition to enforce strategic collaboration in innovative clusters including firms and research institutions based on high demand to solutions and cooperation, which may set new standards in Europe - both concerning products developed and concerning the collaborative setting. The Nordic tradition of functionality in solutions, transparency (in architecture as well as in organisation) and trust between stakeholders are val- 
ues which the network wants to facilitate on an European/international level.

It is the ambition that stakeholders from the SpiCorps network will participate in European projects - as consortia or as individual partners. It is the ambition the stakeholders will be found both in the research community and in business.

Moreover it is the ambition to break the isolation of the construction industry in relation to other business and technology areas, and open up for an understanding that Construction and the built environment has a role to play as a significant potential strategic partner for expanding technologies and economies, in the process of developing human based solutions with high value for society.

\section{List of businesses interested in the project results}

The proposed network thematically covers the construction sector including planning and facilities management and focus on creating support for increasing innovation and competitiveness for specific business groups. The work is not focused on support of specific business groups but rather aiming at setting up framework, practice, tools etc supporting the development ambitions of various sector actors, research groups as well as authorities, clients and end user groups.

Specifically sector representative engaged in the platform:

- The established Nibcor Working Group will be core participants including:

- SBi - Danish Building and Research Institute, Denmark,

- IBRI - Icelandic Building Research Institute, Iceland,

- Tallin University of Technology, Estonia,

- Vilnius Gediminas Technical University, Lituania,

- VTT Technical Research Centre of Finland, Finland,

- SINTEF Bygforsk, Norge,

- ITB, Poland,

- Uppsala University, Sweden.

- Northern Dimension authorities

- Firms' representatives from Nibcor theme groups.

The network will be extended with representatives from firms and R\&D institutions in ICT, Health and Comfort, Energy and Sustainability, Home and Lifestyle. Stakeholders from projects taken place in the NICe will be invited. A special effort will be taken to identify significant stakeholders in the Baltic countries and Poland.

The Norconstruct stakeholders has been contacted and reacted positively for an involvement and coordination between the two platforms. 
The northern national technology platforms, NCTP will be invited to participate. The Nordic NCTP was invited to make a common proposal with the SPiCorps and preferred the indicated cooperation form.

\section{Success criteria}

Short term:

- Establishing contacts to an enlarged number of potential stakeholders in the Northern Region in businesses, research and governmental bodies,

- Coordination with Norconstruct (and the Nordic NCTP),

- Carry out the theme workshops with about 20 participants,

- Contribute to strategic collaboration between SpiCorps stake-holders - in SpiCorps consortia - or in other consortia,

- Contribute to the making of proposals for R\&D projects, of which one or two may success in projects,

- Contribute to effective dissemination activities on two of the workshops and to exhibitions as well.

Long term:

- Contribute to developing products and services based on user values to be produced and/or distributed by firms in the Northern Region,

- Contribute to sustainability and comfort in the built environment,

- Contribute to good standards for completion of collaborative projects,

- Contribute to the break down of isolation and the low reputation of the Construction Sector.

\section{Organization of the project}

The project will be managed by a Steering Group (SG), consisting of the existing Nibcor Steering Group with a member from each of the participating countries and NICe. The SG will be chaired by the project Owner.

An Advisory Board (AB) will be established with representation from NICe projects, Norconstruct, and NCTP's and construction representatives. (Not included in the EOI).

The activities in the project will be organised in the three working groups (WG's) and supported by a secretariat. The thematic content of the working groups are:

- WG1 - Theme workshops will plan and participate in the theme workshop,

- WG2 - Proposal workshops will plan and participate in the proposal workshops, 
- WG3 - Dissemination workshop will plan and participate in the dissemination workshop.

\section{Secretariat (convenor - SBi)}

A secretariat will run the daily work and execute the workshops, delivering information, minutes and reports from the workshops.

There might be a fruitful overlap in participation in the management bodies in the network.

Most of the communication will be on e-mails. Meetings in the management bodies will typical take place in relation to some of the workshops.

\section{Deliverables}

- Workshops for consortia establishment for research proposals for FP7 and other Calls (2, in 2008 and 2009),

- Workshops for proposal preparation (2, in 2008 and 2009),

- Workshop for project dissemination and extended networking (1, in 2009),

- Exhibition for results and solutions for industry, design and research (at the dissemination workshop in 2010),

- Virtual networking and dissemination through the SpiCorps website,

- Leaflets, report and articles.

The Web site deliver information about the project, calls of interest, invitation to workshops, results from workshop, a forum for dating finding partners for collaborative strategic projects. It is suggested that the Nibcor Web site will be adjusted in accordance with this.

An address file is established with potential members for the network - research institutions, firms in construction, firms in expanding technologies and economies, political bodies and stakeholders.

\section{Communication plan}

The established web-site for Nibcor will be changed in accordance with the extended objectives and activities of the project. Start up at project start.

The address file of potential participants in the network will be formed from the existing address file in the Nibcor Project, and supplemented by addresses from the NICe project information. Firms in construction will be contacted through the NCTP's in the Northern Region. Policy bodies will be contacted through the NorConstruct Network. Especially efforts to reach potential stakeholders in the Baltic Countries and Poland will be established. Start up at project start: 
- Invitation to first workshop: May 2008.

- Invitation to each workshop will be distributed especially through the Website and through e-mails. Leaflets will be distributed as well - but only to selected potential stakeholders. Each Workshop will be announced at the web immediately followed by presentations, reports and decisions from the workshop.

- First Theme Workshop: Oct. 2008.

- Report from workshops: November 2008.

- A report with the result from the project will be produced, with specific focus on networking as a tool for establish strategic innovative clusters will be produced. An article with the same topic will be produced for a scientific publication. 